\title{
GROWTH PERFORMANCE AND CARCASS CHARACTERISTICS OF LAMBS FED SPOROBOLUS GRASS HAY GROWN UNDER HIGH SALINITY CONDITIONS
}

\author{
M.H. Abdel Gawad ${ }^{1}$ and G.A. Alhadrami ${ }^{2}$ \\ ${ }^{1}$ Department of Animal Production, Faculty of Agriculture, Cairo University, Giza, Egypt. \\ ${ }^{2}$ Department of Animal Production, College of Food and Agriculture, U.A.E. University, P.O. Box \\ 17555, Al-Ain. UAE.
}

(Received 14/12/2014, accepted 9/2/2015)

\section{SUMMARY}

\begin{abstract}
$\mathrm{T}$ Thirty six, three months old, local and Chios cross-bred male lambs were used to compare three different diets of Rhodes grass (Chloris gayana) hay, Sporobolus (Sporobolus virginicus) grass hay and steam treated (17par/2min) Sporobolus grass hay on growth performance, carcass characteristics, and some blood minerals and metabolites. The experiment lasted for 60 days, with average body weight of 11.01, 10.13, 10.21 Kg of local lambs, and 13.06, 17.78, and $13.92 \mathrm{Kg}$ for Chios cross - bred lambs that offered Rhodes grass hay, Sporobolus grass hay and steam treated Sporobolus grass hay, respectively. The results indicated that, average feed intake, and daily weight gains were significantly $(\mathrm{P}<$ $0.05)$ affected by treatment and breed, while both feed conversion ratio was affected significantly $(\mathrm{P}<0.05)$ by treatments, and water consumption was affected significantly by breed. Feed conversion ratio was almost two folds for crossed lambs fed Sporobolus or those fed steamed sporoblous comparing to the other lambs. Most of lamb's organoleptic carcass traits (carcass weight, full gastro intestinal tract; FGIT, empty gastro intestinal tract; EGIT, head, coat, legs, liver, heart, kidney, lung and abdominal fat) were significantly (P < 0.05 ) affected by breed and insignificantly affected by treatment, except FGIT. Regarding carcass $9^{\text {th }}-11^{\text {th }}$ ribs physical decision and $L$. dorsi chemical analysis, there were no changes among experimental rations, while cross-bred lambs were significantly higher than the local one in all ribs physical composition. Blood chlorine, glucose, and urea were significantly differed by feeding treatment and sodium, gamma glutamyl transpeptidase; GGT and glutamate - pyruvate transaminase; GPT significantly differed by breed. Dressing percentage for Chios cross-bred male fed Rhodes grass hay or those fed steam treated Sporobolus were higher than those fed the other rations. The preliminary results indicated that Sporobolus hay could be used as alternative fodder for lambs growing, especially that local one, instead of Rhodes grass hay in coastal arid regions, with giving more emphasis for the dietary protein supplementation.
\end{abstract}

Keywords: Growing lambs, Rhodes grass, Sporobolus, carcass and blood metabolites.

\section{INTRODUCTION}

In many parts of the world there are scarcity of fresh water resources for irrigation and alternatives using salt tolerant shrubs for animal feeds showed to be beneficial in such areas. Recently, more emphasis was given to the potential role of some unconventional forage and grasses that inhabit, survive and being used as alternative fodder, especially with the marginal, arid and semi arid regions. Halophytes as a source of forage in arid and semi-arid region; where water scarcity, salinity, and poor quality soil are the most distinct characteristics (Arieli et al., 1989; Bhattacharya, 1989; Nunez-Hernandez et al., 1989; Belal et al., 1993; Gihad, 1993 and Gupta, 1993; David et al., 2007 and Papanastasis et al., 2008). These inhabitants are widely distributed throughout the world and unpalatable halophytes are more common and represent about 60-70\% of the natural range-land vegetation in several parts of the world (Gihad, 1994; Zahran, 1993 and El-Shaer, 1999). Several investigators recommended that cultivation of salt and drought tolerant fodder shrubs and salt and drought tolerant grasses and legumes may be an appropriate solution for filling the gap in feed production in arid and saline areas (El-Shaer, 2006 and Hanafy et al., 2007). 


\section{Abdel Gawad and Alhardami}

Sporobolus grass (Sporobolus virginicus) is one of these halophytes, that could be used as an alternative in many areas of arid and semi arid lands (Alhadrami et al., 2003). It is grown successfully under harsh conditions of poor quality soil and saline water ad is giving a considerable biomass (Ahmed and Ismail, 1993; Lieth and Lieth, 1993; Gallagher, 1979; Clarke and Jacoby, 1994 and Naidoo and Nadioo, 1992). Al hadrami et al. (2003) compared the yield, chemical composition and feed intake by camels and sheep from Sporobolus and Rhodes. Rhodes grass (Chloris gayana) is a sub-humid tropical and subtropical perennial grass, which may be irrigated with ground water of low salinity (2500 ppm). Riley and Abdal (1993) reported that sheep offered salicronia salt plant up to $25 \%$ of the diet showed a similar performance $v s$. these fed on alfalfa hay as basal diet. Nunez-Hernandez et al. (1989) found that nitrogen retention and forage intake by goats given a mixture containing forewing saltbush (Atriplex halimus and mountain mahogany) equaled or exceeded those by goats fed on mixture containing alfalfa hay. These results were confirmed by Bhattacharya (1989); Boutouba et al. (1990); Riley and Abdal (1993) and Ben Salem et al. (1994). The objective of this study was to determine growth performance, carcass characteristics and hyagenic impact over blood minerals and metabolite screening of local and Chios cross-bred male lambs fed Sporobolus hay irrigated with high salinity water $(20,000 \mathrm{ppm})$, comparing to the common grass hay being used and irrigated with fresh water (Rhodes grass).

\section{MATERIALS AND METHODS}

The present investigation was carried out at the Research Experimental Station of the United Arab Emirates University, Al-Oha, Al-Ain. Thirty six, three months old, local and Chios cross-bred male lambs were divided randomly into two groups (eighteen for each breed). Each group was divided into three subgroups and assigned randomly to one of the three treatments. The treatments were Rhodes grass hay (Chloris Gayana) as common roughage as a control diet (R); the second treatment was Sporobolus grass hay (Sporobolus virginicus) irrigated with $20.000 \mathrm{ppm}$ saline water (S), and the third one was steam treated (17par/2min) Sporobolus grass hay (SS). A total mixed ration (TMR), of 30: 70\% roughage to concentrate ratio was fed for 60 days for all lambs. Two types of pelleted concentrate containing $14 \%$ and $18 \%$ crude protein were used to compensate the crude protein difference between Rhodes grass and Sporobolus grass diets, to be all isonitrogenous diets for all animals and fulfill the lambs growth requirements as been indicated by NRC (1985). The chemical composition of the experimental diets is shown in Table (1). Feed was offered ad libitum once a day at 7:00 AM. The amounts of feed were adjusted daily to ensure $10-15 \%$ orts. Free intake $(\mathrm{kg} / \mathrm{d})$ and water consumption (L/D) were recorded daily for each animal and body weights were measured weekly, twice a day at morning time at fasting case. The chemical composition of the three experimental diets including crude protein, ether extract, neutral detergent fiber, acid detergent fiber, and ash was determined according the AOAC (1984) based on the dry matter and as average of two random samples (Table 1). All animals were slaughtered at the end of the trial and all organs were weighed.

Table (1): Chemical composition of concentrates, Rhodes grass and Sporobolus grass used as experimental diets (\%, on DM basis).

\begin{tabular}{|c|c|c|c|c|c|}
\hline \multirow[t]{2}{*}{ Ingredient } & \multicolumn{3}{|c|}{ Hay } & \multicolumn{2}{|c|}{ Concentrates } \\
\hline & (R) & $(\mathrm{S})$ & $(\mathrm{SS})$ & $14 \%$ & $18 \%$ \\
\hline Crude protein $(\mathrm{CP})$ & 15.30 & 6.26 & 6.62 & 16.79 & 19.32 \\
\hline Ether extract (EE) & 1.23 & 1.92 & & 1.36 & 1.60 \\
\hline $\mathrm{NDF}$ & 75.97 & 79.75 & 52.01 & 27.49 & 26.85 \\
\hline $\mathrm{ADF}$ & 33.50 & 37.49 & 45.65 & 11.88 & 12.67 \\
\hline Ash & 14.48 & 16.40 & 17.78 & 7.58 & 7.61 \\
\hline
\end{tabular}

$N D F=$ Neutral detergent fiber .

$A D F=$ Acid detergent fiber .

The $9^{\text {th }}, 10^{\text {th }}$ and $11^{\text {th }}$ ribs cuts were taken from the left side of each carcass and physically dissected into lean, fat and bone. Fat thickness $(\mathrm{mm})$ over the $9^{\text {th }}$ rib ad Longissimus dorsi_area $\left(\mathrm{cm}^{2}\right)$ was measured. Chemical composition of the $L$. dorsi muscle was analyzed according to AOAC (1984). Blood Serum samples were collected from each group at monthly interval and analyzed for sodium, glucose, blood urea nitrogen, total protein, albumin, glutamic oxalacetic transaminase (GOT) and glutamic pyrovic 
transaminase (GPT) levels using Dimension Clinical Autoanalyzer (Dupont). The data was analyzed on the light of data represented Meyer et al. (1992). Statistical analyses were conducted using MSTAT; V4 (1989). Differences between treatment means were compared using Duncan's Multiple Range Test.

\section{RESULTS AND DISCUSSION}

\section{Sources and variation:}

Breed and treatment effects were highly significant $(\mathrm{P}<0.01)$ for average daily gains (Table 2). Treatment and breed were significant different in feed intake at $(\mathrm{P}<0.01)$ and $(\mathrm{P}<0.05)$, respectively. Lambs fed on steam treated Sporobolus showed the lowest feed intake and the lowest average daily gains. Cross-bred lambs had higher feed intake and greater weight gains than local lambs regardless the type of the treatments.

Feed intake of Rhodes grass hay was higher than both Sporobolus grass hay (S) and steam treated Sporoboluss. No significant effect of breed was found, while treatments were highly significant $(\mathrm{P}<0.01)$ effect on feed conversion ratio. Water consumption was not affected by treatments while, highly significant differences were recorded among breeds.

Carcass weight and most of the organs weight were not affected significantly by diets, except for the full gastrointestinal trait (Table 3). However, effects of breeds varied from significant $(\mathrm{P}<0.05)$ to highly significant $(\mathrm{P}<0.01)$ for all carcass and organs weights. Testes, tail fat, heart fat, kidneys fat and pelvic fat weights were not affected significantly by breeds.

\section{Intake, water consumption and growth performance:}

Average daily gains (ADG) were 106, 128 and $64 \mathrm{~g} / \mathrm{d}$ for local sheep fed Rhodes, Sporobolus and steam treated Sporobolus, respectively. The same trend was found for feed intake (Table 2). The highest feed intake was recorded on local lambs fed Sporobolus followed by lambs fed Rhodes grass (R) and lambs fed steamed Sporobolus grass (SS). Cross-bred lambs showed the lowest average daily gains and the lowest feed intake when fed SS. They did differ, however, under the other two diets compared to local lambs.

Table (2): Effect of the experimental diets and type of breed on feed intake, average daily gain, feed conversion ratio and water consumption.

\begin{tabular}{|c|c|c|c|c|c|c|c|c|}
\hline \multirow{2}{*}{ Trait } & \multicolumn{2}{|c|}{$\mathrm{R}$} & \multicolumn{2}{|c|}{$\mathrm{S}$} & \multicolumn{2}{|c|}{ SS } & \multicolumn{2}{|c|}{ Significance } \\
\hline & $\mathrm{L}$ & $\mathrm{C}$ & $\mathrm{L}$ & $\mathrm{C}$ & $\mathrm{L}$ & $\mathrm{C}$ & $\mathrm{B}$ & $\mathrm{T}$ \\
\hline Initial wt., $\mathrm{Kg}$ & 11.01 & 13.06 & 10.13 & 17.7 & 10.21 & 13.92 & & \\
\hline Final wt., Kg & 17.37 & 23.86 & 17.81 & 21.6 & 14.71 & 18.42 & & \\
\hline Feed intake (g/d) & $698^{\mathrm{abc}}$ & $948^{\mathrm{a}}$ & $775^{\mathrm{ab}}$ & $523^{\mathrm{c}}$ & $637^{\mathrm{bc}}$ & $637^{\mathrm{bc}}$ & $*$ & $* *$ \\
\hline Average daily gain (g/d) & $106^{\mathrm{bc}}$ & $180^{\mathrm{a}}$ & $128^{\mathrm{a}}$ & $64^{\mathrm{c}}$ & $75^{\mathrm{bc}}$ & $75^{\mathrm{bc}}$ & $* *$ & $* *$ \\
\hline Feed conversion ratio & $4.1^{\mathrm{b}}$ & $5.4^{\mathrm{ab}}$ & $6.2^{\mathrm{ab}}$ & $9.1^{\mathrm{a}}$ & $9.3^{\mathrm{a}}$ & $9.3^{\mathrm{a}}$ & NS & $* *$ \\
\hline Water consumption $(\mathrm{ml} / \mathrm{d})$ & $2560^{\mathrm{bc}}$ & $3320^{\mathrm{a}}$ & $2830^{\mathrm{ab}}$ & 2150 & $2950^{\mathrm{ab}}$ & $2950^{\mathrm{ab}}$ & $* *$ & NS \\
\hline
\end{tabular}

Means in the row followed by different letters differ significantly $(P<0.05)$.

$L=$ Local breed; $C=$ Cross breed.

$B=$ Breed effect $;=$ Treatment effect.

The highest ADG and feed intake were recorded on lambs fed Rhodes grass. Reasons explaining the poor feed intake of lambs fed on SS are unknown, but it could be associated with the presence of some anti-nutritional compounds which adversely affecting on grass palatability and consequently led to a decline of voluntary intake. This phenomenon was reported by Squires (1993) and Gihad and El-Shaer (1994). It could be also due to autoclaving of Sporobolus with high pressure. Temperature and moisture conditions might affect on most of the soluble substances and made the diet unpalatable (Gleen et al., 1992). Order of the burned sugars which resulted from autoclaving could have also an irritant effect on the nasal mucosal membrane of lambs (Irvin, 1980 and Castro et al., 1994). Increased average daily gain of the local breed could be an indication of its tolerance and less susceptibility to salty grass than the crossbred (Bhattacharya, 1989 and Riley and Abdal, 1993). 
Feed conversion ratios (FCR) were higher numerically for SS compared to the other two diets. The latter showed a better FCR, ranging from 4.09 to 5.35. Average water consumption showed that crossbreed lambs consumed more water compared to local lambs. Increased water consumption of cross-bread lambs may be attributed to their highest body weights and feed intake. The total ash content of Sporobolus grass hay was moderate and salt ingestion was inadequate to make the animals suffering adversely (Arieli et al., 1989). The ambient temperature $\left(25-30^{\circ} \mathrm{C}\right)$ was not high enough to a degree which with the salinity would lead to an increase of water consumption. Obtained results from daily feed intake, water consumption, average daily gain and feed conversion ratio indicated that there were insignificant differences among lambs performance when offered Rhodes or Sporobolus grass hay. Moreover; utilization of $(\mathrm{S})$ by local lambs was slightly more efficient than that observed by the cross-bred lambs.

\section{Carcass characteristics and L. dorsi muscle:}

Average carcass weights for local lambs were $8 \mathrm{~kg}, 8.5 \mathrm{~kg}$ and $7.3 \mathrm{~kg}$ for $\mathrm{R}, \mathrm{S}$ and $\mathrm{SS}$ diets, respectively. Cross-bred lambs had heavier weights of $11.9 \mathrm{~kg}, 10.2 \mathrm{~kg}$ and $9.3 \mathrm{~kg}$ for the $\mathrm{R}, \mathrm{S}$ and $\mathrm{SS}$ diets, respectively. Weights of all external organs (head, legs and coat) and some internal organ involving liver, heart, kidneys, spleen and lungs were significantly $(\mathrm{P}<0.01)$ higher in the cross-bred compared with the local breed (Table 3). Neither diets, nor breeds had significant effects on fat deposition at the kidneys, pelvic, heart and tail. There was only one exception of the abdominal fat which was significantly $(\mathrm{P}<$ 0.05 ) affected by breed more than diet, especially with $\mathrm{R}$ diet.

Table (3): Effect of diets and breeds on carcass quality and organoleptic traits.

\begin{tabular}{|c|c|c|c|c|c|c|c|c|}
\hline \multirow{2}{*}{ Trait } & \multicolumn{2}{|c|}{$\mathrm{R}$} & \multicolumn{2}{|c|}{$S$} & \multicolumn{2}{|c|}{ SS } & \multicolumn{2}{|c|}{ Significance } \\
\hline & $\mathrm{L}$ & $\mathrm{C}$ & $\mathrm{L}$ & $\mathrm{C}$ & $\mathrm{L}$ & $\mathrm{C}$ & B & $\mathrm{T}$ \\
\hline \multicolumn{9}{|c|}{ Carcass and external weights, $\mathrm{Kg}$} \\
\hline Carcass wt. & $8.04^{\mathrm{b}}$ & $11.91^{\mathrm{a}}$ & $8.49^{\mathrm{b}}$ & $10.22^{\mathrm{ab}}$ & $7.30^{\mathrm{b}}$ & $9.31^{\mathrm{ab}}$ & $* *$ & NS \\
\hline FGIT wt. & $4.66^{\mathrm{abc}}$ & $5.96^{\mathrm{a}}$ & $4.31^{\mathrm{bc}}$ & $5.55^{\mathrm{ab}}$ & $3.24^{\mathrm{c}}$ & $3.78^{\mathrm{c}}$ & $*$ & $*$ \\
\hline EGIT wt. & $1.52^{\mathrm{ab}}$ & $1.76^{\mathrm{a}}$ & $1.55^{\mathrm{ab}}$ & $1.85^{\mathrm{a}}$ & $1.21^{\mathrm{b}}$ & $1.57^{\mathrm{ab}}$ & $*$ & NS \\
\hline Head wt. & $1.27^{\mathrm{b}}$ & $1.52^{\mathrm{a}}$ & $1.29^{\mathrm{b}}$ & $1.54^{\mathrm{a}}$ & $1.28^{\mathrm{b}}$ & $1.59^{\mathrm{a}}$ & $*$ & NS \\
\hline Coat wt. & $1.87^{\mathrm{bc}}$ & $2.61^{\mathrm{a}}$ & $2.15^{\mathrm{abc}}$ & $2.45^{\mathrm{ab}}$ & $1.58^{\mathrm{c}}$ & $2.08^{\mathrm{abc}}$ & $*$ & NS \\
\hline Legs wt. & $0.55^{\mathrm{ab}}$ & $0.56^{\mathrm{ab}}$ & $0.56^{\mathrm{ab}}$ & $0.64^{\mathrm{a}}$ & $0.47^{b}$ & $0.62^{\mathrm{ab}}$ & $* *$ & NS \\
\hline \multicolumn{9}{|c|}{ Internal organoleptic weights, $g$} \\
\hline Liver wt. & $335^{b}$ & $489^{a}$ & $366^{\mathrm{ab}}$ & $479^{\mathrm{ab}}$ & $323^{b}$ & $421^{\mathrm{ab}}$ & $* *$ & NS \\
\hline Heart wt. & $88^{\mathrm{b}}$ & $119^{a}$ & $85^{\mathrm{b}}$ & $98^{\mathrm{ab}}$ & $69^{b}$ & $93^{\mathrm{ab}}$ & $* *$ & NS \\
\hline Kidneys wt. & $60^{\mathrm{bc}}$ & $86^{\mathrm{a}}$ & $65^{\mathrm{abc}}$ & $79^{\mathrm{ab}}$ & $56^{\mathrm{c}}$ & $77^{\mathrm{abc}}$ & $* *$ & NS \\
\hline Spleen wt. & $27^{\mathrm{ab}}$ & $34^{\mathrm{a}}$ & $22^{b c}$ & $35^{\mathrm{a}}$ & $16^{\mathrm{c}}$ & $30^{\mathrm{ab}}$ & $* *$ & NS \\
\hline Lunge wt. & $233^{b c}$ & $305^{\mathrm{ab}}$ & $234^{b c}$ & $309^{a}$ & $187^{\mathrm{c}}$ & $280^{\mathrm{ab}}$ & $* *$ & NS \\
\hline Testes wt. & 83 & 153 & 100 & 125 & 78 & 98 & NS & NS \\
\hline Tail fat wt. & 240 & 400 & 263 & 367 & 192 & 220 & NS & NS \\
\hline Heart fat & 22 & 29 & 21 & 27 & 15 & 21 & NS & NS \\
\hline Abdominal fat & 217 & 498 & 293 & $251^{\mathrm{ab}}$ & 244 & $222^{\mathrm{b}}$ & $*$ & NS \\
\hline Kidneys fat & 157 & 268 & 194 & 120 & 154 & 141 & NS & NS \\
\hline Pelvic fat & 125 & 189 & 136 & 132 & 125 & 155 & NS & NS \\
\hline Dressing \% & 46.29 & 49.90 & 47.67 & 47.27 & 49.62 & 50.51 & & \\
\hline
\end{tabular}

Means in the same row followed by different letters differ significantly $(P<0.05)$.

*Significantly at 0.05; ** Significantly at 0.01 and NS: No Significant.

Ribs weight and fat thickness were significantly $(\mathrm{P}<0.05)$ higher in the cross-bred compared with the local lambs (Table 4). Physical dissection and chemical composition of Longisimus dori (L. Dorsi) muscle is shown in Table (4), and all physical traits of the eye muscle were insignificantly affected by diets. However significant $(\mathrm{p}<0.05)$ difference between breeds were detected, exception made for bone percentage were highly significant. Neither treatments nor type of breed have significant influence on $L$. dorsi area and all chemical composition analysis including ash, crude protein and ether extract (Table 4). The significant influences of the physical traits of the dorsi muscle between the local and cross-bred lambs may be attributed to the biggest skeleton and the higher initial live weight of the cross-bred compared with the local one. Measurements concerning carcass evaluation and L. dorsi muscle characteristics indicated that different tested diets had no effect. In most case the type of breed was only the valuable factor affecting carcass traits and physicochemical pattern of L. dorsi muscle. Carcass characteristics results are agree with the findings of Nawaz et al. (1994) which reported that carcass quality and organoleptic traits 
of Pakistan dwarf goats were insignificantly differences of the physical traits on the dorsi muscle between the local and cross-bred lambs may be attributed to the biggest skeleton and the higher initial live weight of the cross-bred compared with the local one.

Table (4): Effect of experimental diets and breed on the $11^{\text {th }}$ ribs dissection and $L$. dorsi muscle composition.

\begin{tabular}{|c|c|c|c|c|c|c|c|c|}
\hline \multirow{2}{*}{ Trait } & \multicolumn{2}{|c|}{$\mathrm{R}$} & \multicolumn{2}{|c|}{$\mathrm{S}$} & \multicolumn{2}{|c|}{ SS } & \multicolumn{2}{|c|}{ Significance } \\
\hline & $\mathrm{L}$ & $\mathrm{C}$ & $\mathrm{L}$ & $\mathrm{C}$ & $\mathrm{L}$ & $\mathrm{C}$ & $\mathrm{B}$ & $\mathrm{T}$ \\
\hline \multicolumn{9}{|c|}{ Physical dissection of the ribs cut: } \\
\hline Rib wt. (g) & $208^{b}$ & $349^{a}$ & $246^{\mathrm{ab}}$ & $293^{\mathrm{ab}}$ & $206^{\mathrm{b}}$ & $249^{\mathrm{ab}}$ & $*$ & NS \\
\hline Muscle wt. (g) & $31^{\mathrm{b}}$ & $52^{\mathrm{a}}$ & $40^{\mathrm{ab}}$ & $39^{\mathrm{ab}}$ & $26^{\mathrm{b}}$ & $34^{\mathrm{b}}$ & * & NS \\
\hline Lean $(\%)$ & $30.2^{\mathrm{b}}$ & $29.7^{\mathrm{a}}$ & $32.2^{\mathrm{ab}}$ & $32.2^{\mathrm{ab}}$ & $29.9^{b}$ & $30.8^{\mathrm{ab}}$ & * & NS \\
\hline Fat $(\%)$ & $24.0^{\mathrm{b}}$ & $31.9^{\mathrm{a}}$ & $32.4^{\mathrm{ab}}$ & $28.6^{\mathrm{ab}}$ & $24.6^{\mathrm{b}}$ & $25.9^{\mathrm{ab}}$ & * & NS \\
\hline Bone $(\%)$ & $45.8^{\mathrm{a}}$ & $38.5^{\mathrm{b}}$ & $35.4^{\mathrm{b}}$ & $39.2^{\mathrm{b}}$ & $45.6^{\mathrm{a}}$ & $43.3^{\mathrm{ab}}$ & $* *$ & NS \\
\hline $\operatorname{LDA}\left(\mathrm{cm}^{2}\right)$ & 5.4 & 5.3 & 4.7 & 5.1 & 5.4 & 5.2 & $\mathrm{NS}$ & NS \\
\hline FT (mm) & $2.25^{\mathrm{b}}$ & $3.4^{\mathrm{a}}$ & $2.83^{\mathrm{b}}$ & $3.1^{\mathrm{b}}$ & $2.33^{\mathrm{b}}$ & $2.42^{\mathrm{b}}$ & $*$ & NS \\
\hline \multicolumn{9}{|c|}{ Chemical composition of $L$. dorsi muscle: } \\
\hline Protein $(\%)$ & 84.10 & 82.98 & 82.72 & 83.26 & 83.76 & 83.07 & NS & NS \\
\hline Ether extract $(\%)$ & 10.20 & 9.46 & 11.84 & 9.74 & 10.43 & 8.73 & NS & NS \\
\hline $\operatorname{Ash}(\%)$ & 5.37 & 5.25 & 4.67 & 5.11 & 5.39 & 5.16 & $\mathrm{NS}$ & NS \\
\hline
\end{tabular}

Means in the same row followed by different letters differ significantly $(p<0.05)$.

*Significantly at 0.05; ** Significantly at 0.01 and NS: No Significant.

$L D A=$ Longissimus dorsi area .

$F T=$ Fat thickness .

\section{Blood minerals, metabolites and enzymes:}

Effect of feeding of Rhodes, Sporobolus and steamed Sporobolus on both local and cross bred lambs on blood minerals, metabolites and hormones are shown in Table (5). Most of blood metabolites $(\mathrm{Mg}, \mathrm{Cu}$, Creatinine, CK, LD, AST, and total protein) were insignificantly affected by breed and treatment. Most of the tested blood minerals, metabolites and enzymes were normally referenced to Ghergariu (1995), and Pârvu (1992) and Meyer et al. (1992). Plasma sodium level in cross lambs showed significant increase comparing to local breeds.

Table (5): Effect of experimental diets and lambs breed on plasma minerals, metabolites and enzymes.

\begin{tabular}{|c|c|c|c|c|c|c|c|c|}
\hline \multirow{2}{*}{ Traits } & \multicolumn{2}{|c|}{$\mathrm{R}$} & \multicolumn{2}{|c|}{$S$} & \multicolumn{2}{|c|}{ SS } & \multicolumn{2}{|c|}{ Significance } \\
\hline & $\mathrm{L}$ & $\mathrm{C}$ & $\mathrm{L}$ & $\mathrm{C}$ & $\mathrm{L}$ & $\mathrm{C}$ & $\mathrm{B}$ & $\mathrm{T}$ \\
\hline $\mathrm{Na}, \mathrm{mmol} / \mathrm{L}$ & $134.2^{\mathrm{ab}}$ & $135.4^{\mathrm{ab}}$ & 136.1 & $138^{\mathrm{a}}$ & $135.8^{\mathrm{ab}}$ & $133.7^{b}$ & $*$ & NS \\
\hline $\mathrm{Mg}, \mathrm{mg} \%$ & 1.97 & 1.97 & 2.04 & 2.13 & 1.90 & 1.98 & NS & NS \\
\hline $\mathrm{Cu}, \mathrm{mg} / \mathrm{dL}$ & 105.9 & 100.7 & 102.4 & 104.8 & 112.2 & 94.83 & NS & NS \\
\hline $\mathrm{Cl}, \mathrm{mmol} / \mathrm{L}$ & $102.9^{b}$ & 106.1 & 102.4 & $105.5^{\mathrm{a}}$ & $105.2^{\mathrm{ab}}$ & $104.3^{\mathrm{ab}}$ & NS & $*$ \\
\hline Glucose, $\mathrm{mg} / \mathrm{dL}$ & $87.6^{\mathrm{abc}}$ & $84.9^{\mathrm{abc}}$ & $90.9^{\mathrm{a}}$ & $90.1^{\mathrm{ab}}$ & $81.2^{\mathrm{bc}}$ & $79.2^{\mathrm{c}}$ & NS & $* *$ \\
\hline Urea-N, mg/dL & $21.2^{\mathrm{a}}$ & $19.0^{\mathrm{ab}}$ & $19.2^{\mathrm{ab}}$ & $20.3^{\mathrm{ab}}$ & $19.7^{\mathrm{ab}}$ & $17.6^{\mathrm{b}}$ & NS & $*$ \\
\hline Creatinine, $\mathrm{mg} / \mathrm{dL}$ & 0.62 & 0.61 & 0.58 & 0.57 & 0.61 & 0.60 & NS & NS \\
\hline $\mathrm{CK}(\mathrm{cpk}), \mu / \mathrm{L}$ & 382.2 & 295.4 & 377.5 & 288.1 & 335.7 & 286.3 & NS & NS \\
\hline $\mathrm{LD}(\mathrm{LDH}-\mathrm{L}), \mu / \mathrm{L}$ & 405.8 & 377.3 & 377.6 & 372.6 & 325.2 & 378.7 & NS & NS \\
\hline GGT, $\mu / \mathrm{L}$ & $137.3^{\mathrm{ab}}$ & $119.2^{\mathrm{c}}$ & $132.5^{b}$ & $116.7^{\mathrm{c}}$ & $151.4^{\mathrm{a}}$ & $118.2^{\mathrm{c}}$ & $* *$ & NS \\
\hline $\operatorname{ALT}(\mathrm{GPT}), \mu / \mathrm{L}$ & $25.4^{\mathrm{a}}$ & $20.2^{\mathrm{ab}}$ & 16.4 & $16.6^{\mathrm{ab}}$ & $12.1^{b}$ & $19.7^{\mathrm{ab}}$ & $* *$ & NS \\
\hline AST (GOT), $\mu / \mathrm{L}$ & 129.4 & 104.8 & 129.9 & 128.6 & 103.4 & 107.5 & $\mathrm{NS}$ & NS \\
\hline Total protein, g/dL & 6.09 & 6.03 & 6.15 & 6.18 & 6.22 & 6.18 & NS & NS \\
\hline Albumin, g/dL & $2.92_{\mathrm{ab}}$ & $3.15^{\mathrm{a}}$ & 2.99 & $3.06^{\mathrm{ab}}$ & $2.82^{\mathrm{b}}$ & $2.98^{\mathrm{ab}}$ & $*$ & NS \\
\hline
\end{tabular}

Means in the same row followed by different letters differ significantly $(P<0.05)$.

*Significantly at 0.05; ** Significantly at 0.01 and NS: No Significant. 
Sprorobolus grass significantly increased glucose in plasma comparing to the other diets, while were insignificantly lower with the steam treated Sporobolus, which indicating that heating might burn carbohydrate compounds and being very low in Sporobolus steam treated (Millard reaction ). Decreasing blood glucose level with lambs fed the heat treated Sporobolus could be attributed for burning more soluble carbohydrate under thermal and pressure effect, which indicating lower energy status of the grass. Concerning the effect of steam treatment on nutrients digestibility, were significantly lower compared with the untreated Sporobolus grass hay may be due to the increase of digestible nitrogen loss which is associated with fiber composing acid detergent insoluble nitrogen (ADIN) complex as described by Castro et al. (1994).

In addition, steam treatment produces some anti-nutritional factors resulting from Brown reaction or Millard reaction like furfural which has irritant effect for the mucosal membrane of animal's nose and reduces dry matter intake as well (Irvin, 1980 and Castro et al., 1994). In contrary feeding protein with high rumen un-degradable value resulted in increased concentration of blood glucose due to more glucogenic amino acids available for gluconeogenesis (Khalid et al., 2012). Local lambs fed Sporobolus grass significantly showed higher concentration of GGT, and local breed fed Rhodes grass showed significantly the highest level of blood GPT. Analyzing data for metabolic profile of lambs, it was found that the protein profile highlights normal levels of albumin and creatinine. Plasmatic urea nitrogen concentrations in all lambs were insignificantly differed and almost represent half of the normal value as reported by Merck and Dohme (1991). However, lambs fed salt tolerant grass (Sporobolus verginicus), the plasma sodium level was almost normal and insignificantly different than lambs consumed Rhodes grass. Nevers less the total plasma protein insignificantly differed among all lambs, the albumin level was significantly $(\mathrm{p}<0.05)$ differed and being highest for cross bred fed Rhodes and lowest for local breed fed steam treated Sporobolus. One of particular importance for diagnosis is a muscle enzyme activity (AST, CPK), liver (AST and GGT), results of blood biochemical examination of all the lambs taken in this study highlight a significant deference of GPT (ALT) and GOT (AST). Aspartate aminotransferase (AST) was insignificantly changed among all treatments, breeds, and cross breeds. Alkaline hiperphosphatazemia of hepatic origin is accompanied by significant increase of GGT in local lambs fed steam treated Sporobolus.

\section{CONCLUSION}

Exploring the possibility of using salt tolerant grass for lambs nutrition in arid and semi-arid regions, it could be concluded that Sporobolus grass hay (Sporobolus viriginicus) is considered an acceptable substitute or alternative forage for sheep in coastal arid zones. For better feeding performance and avoiding deleterious effects, Sporobolus could be offered with another portion of protein supplement materials. More research needs to be conducted to explore the effect of long term feeding of salt tolerant grass on lamb's growth.

\section{REFERENCES}

AOAC (1984). Official Methods of Analysis. Assoc. (14 th ed) Offic. Chem., Washington, D.C., USA.

Arieli, A.; E. Nairn; R.W. Benjamin and D. Pasternak (1989). The effect of feeding saltbush and sodium chloride on energy metabolism in sheep. Anim. Prod., 49: 445-457.

Ahmed, R. and S. Ismail (1993). Studies on selection of salt-tolerant lants for food, fodder and fuel from world flora. Towards the rational use of high salinity tolerant plants. Vol. 2: 295-304. Kluwer Academic Publishers, Netherlands.

Alhadrami, G.A.; A.J. Al-Dkheel; M.M. Khorshid; S.A. Al-Sharaby and M.H. Abdel Gawad (2003). Feeding camels and sheep Sporobolus grass grown in saline desert land in United Arab Emirates. In: Wood, W.W., Goudie, A.S., Fowler, A., Abdellatif, E.M. (Eds.), Proceedings of Dubai International Conference on Desertification. Swets and Zeitling, pp. 183-186.

Belal, A.H.; A.M. Rammah; M.S. Hopkin; L.D. Hansen and E.D. McArthur (1993). Studies of salttolerance and chemical analysis of fodder shrubs in Egypt and Utah (USA). Towards the rational use of high salinity tolerant plants. Vol(2): 213-220. Kluwer Academic Publishers, Netherlands. 
Ben Salem, H.; J.A. Efzaoui and H. Abdouli (1994). Paltability of shrubs and fodder trees measured on sheep and dromedaries: 1. Methodological approach. Animal Feed Science and Technology, 46: 143153.

Bhattacharya, A.N. (1989). Nutrient utilization of accacia, haloxylan and atriplex species by Najdi sheep. J. of Range Management, 42(1): 28 - 31.

Boutouba, A.; J.L. Holechek; M.L. Galyean; G. Nunez-Hernandez; J.D. Wallace and M. Cardenas (1990). Influence of two native shrubs on goat nitrogen status. Journal of Range Management, 43(6): 530-534.

Castro, F.B.; P.M. Hotten; E.R. Ørskov and M. Rebeller (1994). Inhibition of rumen microbes by compounds formed in the steam treatment of wheat straw. Bio-resource Technology, 50: 25-30.

Clarke, P.J. and C.A. Jacoby (1994). Biomass and above-ground productivity of salt-marsh plants in south-easternAustralia. Australian Journal of Marine and Freshwater Research, 45(8): 1521-1528.

David, G. Masters; E.B. Sharon and C.N. Hayley (2007). Biosaline agriculture for forage and livestock production. Agriculture, Ecosystems and Environment, 119: 234-248.

El Shaer, H.M. (1999). Potentiality of animal production in the Egyptian desert region. In: Proceedings of the Conference on Animal Production in the 21st Century Challenges and Prospects, 18-20 April 2000, Sakha, Kafr El Sheikh, Egypt, pp. 93-105.

El Shaer, H.M. (2006). Halophytes as cash crops for animal feeds in arid and semi-arid regions. In: Ozturk, M., Waisel, Y., Khan, M.A., Gork, G. (Eds.), Biosaline Agriculture and High Salinity Tolerance in Plant. Birkhauser, Basel, pp. 117-128.

Gallagher, J.L. (1979). Growth and element compositional responses of Sporobolus virginicus (L.) Kunth to substrate salinity and nitrogen. The American Midland Naturalist, 102(1): 68-75.

Ghergariu, S. (1995). Bazele patologiei medicale a animalelor, Ed. All, Bucureşti.

Gihad, E.A. and H.M. El-Shaer (1994). Utilization of halophytes by livestock on rangelands, problems and prospects. Halophytes as a resource for livestock and for rehabilitation of degraded lands. 77-96, Kluwer Academic Publishers, Netherlands.

Gihad, E.A. (1993). Utilization of high salinity tolerant plants and saline water by desert animals. Towards the rational use of high salinity tolerant plants. Vol. 1:443-447. Kluwer Academic Publishers, Netherlands.

Glenn, E.P.; W.E. Coates; J.J. Riley; R.O. Kuehl and R.S. Swingle (1992). Salicronia bigelovii Torr. a seawater-irrigated forage for goats. Animal Feed Science and Technology, 40(1): 21-30 (Abst.)

Gupta, R.K. (1993). Utilization of salt tolerant plants from arid wastelands of Northwest India as fuel and fodder. Towards the rational use of high salinity tolerant plants, Vol. 2:247-257. Kluwer Academic Publishers, Netherlands.

Hanafy, M.A.; A.A. Fahmy; M.S. Farghaly and A. El Sheref (2007). Effect of using some fodder plants in diets on goat's performance under desert conditions of Sinai. Egyptian J. Nutr. Feeds, 10: 151-163.

Irvin, E.L. (1980). Toxic Constituents of Plant Foodstuffs ( $2^{\text {nd }}$ ed.) Academic press, Fifth Avenue, New York 10003, USA.

Khalid, M.F.; M. Sarwar; A.U. Rehman; M.A. Shahzad and N. Mukhtar (2012). Effect of Dietary Protein Sources on Lamb's Performance: A Review. Iran. J. Applied Anim. Sci., 2(2): 111-120.

Lieth H. and A. Lieth (1993). Seawater irrigation studies in the United Arab Emirates; an introduction to the Al Ain Conference. Towards the rational use of high salinity tolerant plants. 1:1-10. Kluwer Academic Publishers, Netherlands.

Merck, S. and F. Dohme-irm (1991). The Merck Veterinary Manual: A handbook of diagnosis, therapy, and disease prevention and control for the veterinarian. Seventh edition. Rahway, N.J.: Merck \& Co., Inc.

Meye,r J.D; H.E Coles and J.L. Rich (1992). Veterinary laboratory medicine, interpretation and diagnosis. Published byW.B. Saunders company.

MSTAT (1989). Nisson, O. Michigan State Univ. Statistical package. Dept. of Crop and Soil Science, Michigan State Univ., E. Lansing, Michigan 48824. USA. 
Naidoo G. and S. Naidoo (1992). Waterlogging responses of Sporobolus virginicus (L.) Kunth. Oecologia, 90(3): 445-450

Nawaz, S.; S.H. Hanjra; R.H. Qureshi; V.R. Squires and A.T. Ayoub (1994). Effect of feeding atriplex amnicola on growth and carcass quality of dwarf goats. Proceedings of the International workshop on halophytes for reclamation of saline wastelands and as a resource for livestocks-problems and prospects, Nairobi, Kenya, 22-27 Nov., 277-280 (Abst.).

NRC (1985). National Research Council: Nutrient Requirements of Sheep. Sixth Revised Edition. National Academy Press, Washington, D.C.

Nunez-Hernandez, G.; J.L. Holechek; J.D. Wallace; M.L. Galyean; A. Tembo; R. Valdez and M. Cardenas (1989). Influence of native shrubs on nutritional status of goats: nitrogen retention. Journal of Range Management, 42(3): 228-232.

Papanastasis, V.P.; M. D. Yiakoulaki; M. Decandia and O. Dini-Papanastasi (2008). Integrating woody species into livestock feeding in the Mediterranean areas of Europe. Anim. Feed Sci. Technol., 140: 117.

Pârvu, Gh. (1992). Supravegherea nutriŃional-metabolică a animalelor, Ed. Ceres, Bucureşti.

Riley, J.J. and M. Abdal (1993). Preliminary evaluation of salicronia production and utilization in Kuwait. Towards the rational use of high salinity tolerant plants. Vol. 2:319-329, Kluwer Academic Publishers, Netherlands.

Squires, V.R. (1993). Australian experiences with high salinity diets for sheep. Towards the rational use of high salinity tolerant plants. Vol. 1:449-457. Kluwer Academic Publishers, Netherlands.

Zahran, M.A. (1993). Juncus and Kochia: fiber and fodder producing halophytes under salinity and aridity stresses. In: Pessarakli, M. (Ed.), Handbook of Plant and Crop Stress. Marcel Dakker, Inc., NY, pp. 505-530. 


\title{
آداء النمو وخصائص الذبيحة لحملان غذيت على دريس حشيشة سبورويولس نمت تحت ظروف ملحية مرتفعة
}

\author{
محمد حسن عبد الجواد1 و غالب علي الحضرمي²

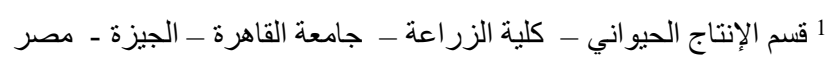

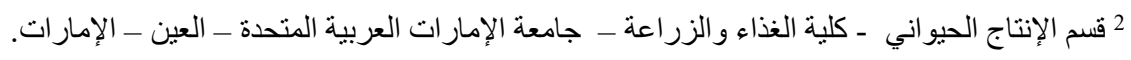

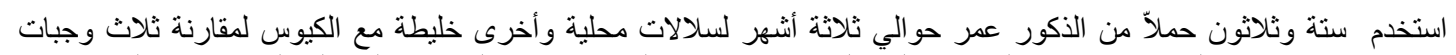

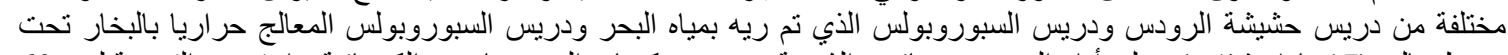

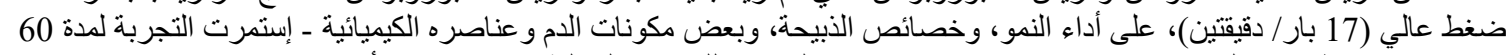

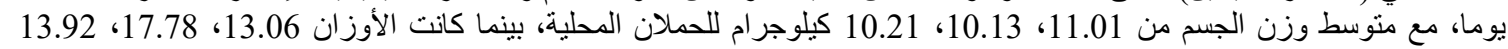

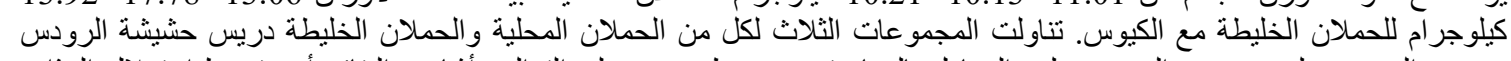

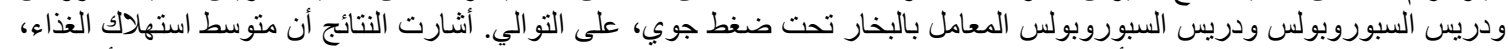

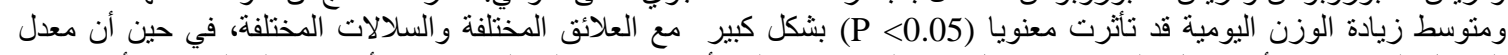

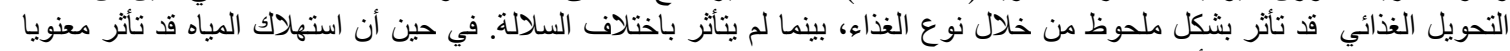

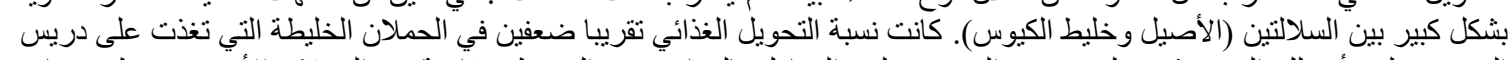

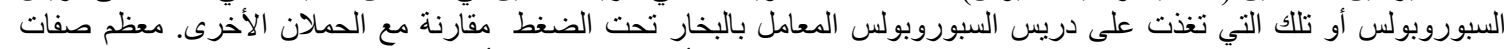

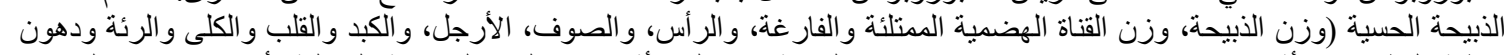

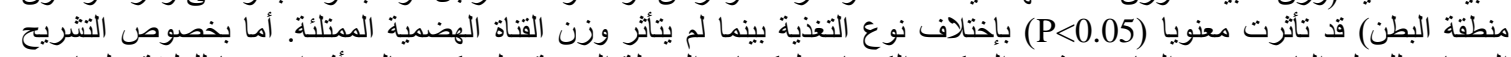

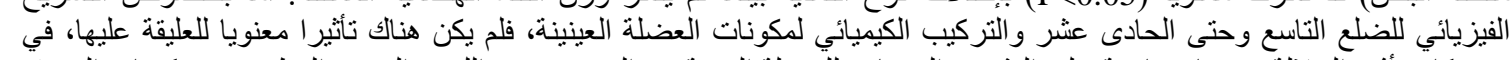

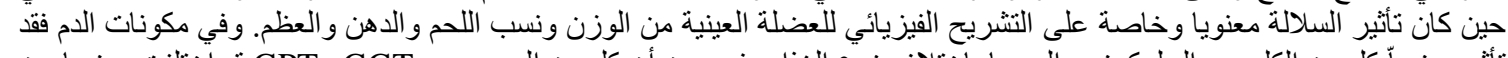

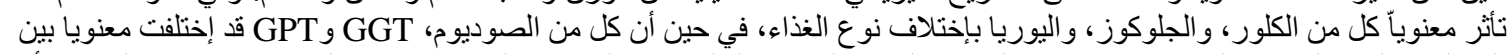

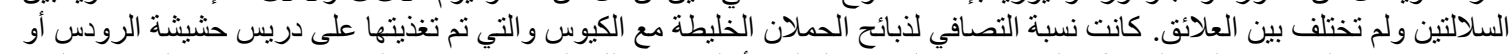

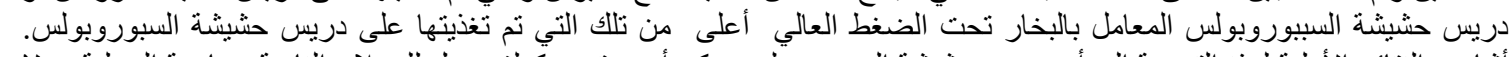

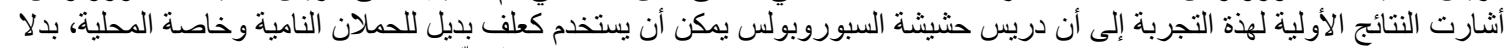

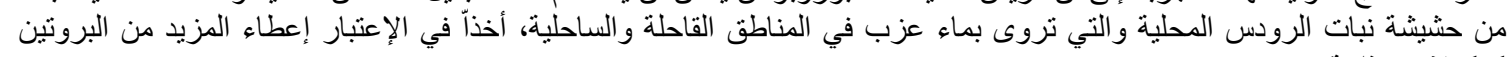
كمكملات غذائية. الكلمات الدالة: الحملان النامية ، حشيشة الرودس ، حشيشة سبوروبولس، الذبيحة، الأيض والأملاح بالدم. 